African Journal of Cellular Pathology 4: 70-73 (2015)

The Official Journal of the Society for Cellular Pathology Scientists of Nigeria

www.ajcpath.com

\title{
ISOLATION AND SEROLOGICAL DETECTION OF MYCOPLASMA GALLISEPTICUM AND MYCOPLASMA SYNOVIAE USING A COMBINED MG/MS ENZYME-LINKED IMMUNOSORBENT ASSAY KIT IN INDIGENOUS CHICKENS IN NIGER STATE, NIGERIA
}

\author{
Ahmed JS1, Lawal SM2, Fatihu MY3, Moses DG1, Barde IJ1, Kumbish PR1, Oladele SB3
}

1. Central Diagnostic Laboratory, National Veterinary Research Institute Vom, Plateau State Nigeria.

2. Poultry Unit, A.B.U. Veterinary Teaching Hospital, Faculty of Veterinary Medicine, Ahm adu Bello University, Zaria, Nigeria

3. Dept of Veterinary Pathology, Faculty of Veterinary Medicine, Ahmadu Bello University, Zaria, Nigeria

Corresponding Author: Ahmed JS

Email: etsujames@yahoo.com

\begin{abstract}
Aim: The present study was undertaken to determine the seroprevalence of mycoplasma infection and possible isolation from local chickens in Niger State, Nigeria. We have looked into this problem using a combined MG/MS ELISA kit and cultural isolation.

Methods: A total of 552 blood samples were randomly collected from exanguinated chickens for serology. Tracheal swabs were collected into screwed cap bijou bottles containing $2 \mathrm{ml}$ of mycoplasma broth medium.

Results: The sero prevalence of indigenous chickens from Niger State was $91.83 \%$ by MG/MS Elisa. A total of 126 swabs yielded to the growth of avian mycoplasma on mycoplasma agar.
\end{abstract}

Key words: Isolation, Mycoplasma species, Avian, indigenous chickens.

\section{INTRODUCTION}

Mycoplasmosis is one of the important disease problems of poultry in Nigeria, and it affects both commercial exotic breeds and indigenous breeds (Abdu et al., 1983). The most important mycoplasmas for chickens, turkeys and other avian species are Mycoplasma gallisepticum (MG), M. synoviae (MS), and M. meleagridis. Mycoplasmas are bacteria that lack cell wall and belong to the class Mollicutes (Barua et al., (2006) and Bradbury, 2001). As in other poultry producing countries, avian mycoplasma infection causes decreased feed efficiency, poor carcass quality and sub-optimal egg production in layer chickens, turkeys and other avian species (Hossain et al., 2007). The infection appears to be world-wide in distribution and is transmitted both horizontally and vertically and it can remain in the flock constantly in a subclinical form (Bencina et al., 1988). Avian Mycoplasmosis may be diagnosed serologically or by morphology of causal agents, cultural characteristics, physical, biochemical properties (Ley and Yoder, (1997) Serology is the only reliable tool for detecting the subclinical infection in a flock (Pradhan, 2002). Indigenous chickens which constitute the majority of the chicken population in northern Nigeria are mainly kept under extensive management system, where they roam freely and scavenge for food. Their movement is uncontrolled and they hardly receive any prophylactic treatment or vaccination (Olabode et al., 1992). It is believed that these free roaming chickens act as reservoirs and carriers of infections to themselves and susceptible exotic breeds in commercial enterprises (Adegboye, 1983). Indigenous chickens are been used in small scale backyard poultry production in Niger State, Nigeria to support the fast growing human population with high quality protein. The importance of indigenous chicken production 
cannot be over emphasized because of the divergent roles it plays; sale of eggs and live birds in urban and rural markets as the only source of earnings available to rural families. Indigenous Chickens are also used traditionally as a means of knowing the time, offered as gifts and in cementing marriages and friendship. The present study was undertaken to determine the seroprevalence of mycoplasma infection and possible isolation from local chickens in Niger State, Nigeria.

\section{MATERIALS AND METHODS Study Area}

Niger State is situated in the middle belt region of Nigeria and lies between latitude $8^{\prime} 00^{\prime \prime}$ and $13^{\prime} 30^{\prime \prime}$ North and longitude $4^{\prime} 20^{\prime \prime}$ and $8^{\prime} 40^{\prime \prime}$ East, where livestock and animal husbandry constitute a major subsistence focus of the people. There are three geographical zones in Niger State, namely Kontagora, Minna and Bida.

\section{Blood Sampling and Serum Preparation}

Six millilitres of blood were collected aseptically by exsanguination into a vacutainer tube and then slanted and allowed to clot. A total of 552 blood samples were randomly collected. The sera were decanted into labelled Ependoff tubes and stored on ice packs, and there after sent to the Mycoplasma Research Laboratory National Veterinary Research Institute, Vom for analysis.

\section{Enzyme-Linked Immunosorbent Assay} (ELISA)

Commercial Mycoplasma gallisepticum (MG) and M. synoviae (MS) ELISA kits were purchased from Biochek ${ }^{R}$ veterinary diagnostics in Holland and used according to the manufacturer's recommendations. The MG/MS ELISA kit measures the amount of both antibodies to MG/MS in the serum of chickens.

\section{Culture Procedure}

Sterile cotton buds were used to swab the trachea of live birds. The buds were cut, put in a screw capped bijou bottle containing $2 \mathrm{ml}$ of mycoplasma broth medium and packed in a cold flask before they sent to the Mycoplasma Research Laboratory, N.V.R.I. where they were incubated at $37{ }^{\circ} \mathrm{C}$ for 5 days. The bottles were examined every 24 hours for change in colour of the media from alkaline (pinkish) to slightly acidic (orange-yellow). To check for colonies, 20 microlitre of each liquid culture was serially diluted to $1 \times 10^{-10}$ and the last portions were then inoculated on mycoplasma agar plates and incubated at $37{ }^{\circ} \mathrm{C}$ in a glass anaerobic jar. The plates were examined every 24 hours for Mycoplasma like colonies using a stereoscopic microscope at a magnification of x140 to x 180 . Inoculated plates were incubated for about 10 days before they were considered negative for isolation. The Mycoplasma-like colonies were identified as organisms with opaque colonies granular with central raised area (nipple) and surrounded by a translucent periphery.

\section{RESULTS}

Table 1: Seroprevalence of Mycoplasma gallisepticum and M. synoviae in local chickens

\begin{tabular}{lcccc} 
Location & $\mathrm{n}$ & No. positive & No. negative & (prevalence \%) \\
Kontagora & 184 & 173 & 11 & $(94.02)$ \\
Minna & 184 & 170 & 14 & $(92.39)$ \\
Bida & 184 & 164 & 20 & $(89.13)$ \\
\hline Total & 552 & 507 & 45 & $(91.84)$ \\
\hline
\end{tabular}

$\mathrm{p}=0.2178 ; \quad \mathrm{X}^{2}=3.049$

Table 1 shows the seroprevalence of Mycoplasma gallisepticum and M. synoviae antibodies in local chickens using MG/MS ELISA (for both Mycoplasma gallisepticum and Mycoplasma synoviae) from the three geographical zones in Niger State. Kontagora, Minna and Bida had prevalence of 94.02\%, 92.39\% and 89.13\% respectively. The overall seroprevalence of Mycoplasma gallisepticum and M. synoviae in indigenous chicken from Niger State was $91.83 \%$ by MG/MS Elisa. 


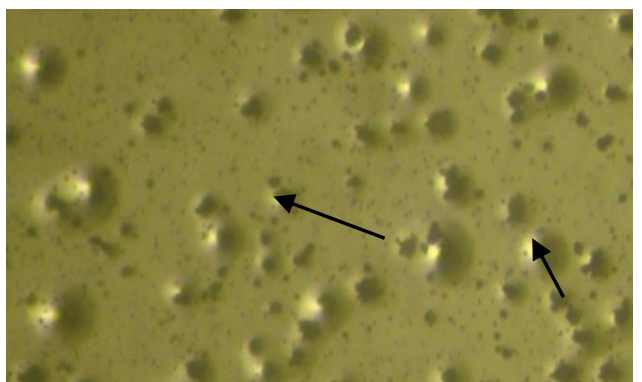

Plate: 1 showing avian Mycoplasma colonies on PPLO agar plates. Note the round raised central dark area (nipple) and a translucent periphery (black arrows), X45. Out of the total 138 swabs taken, 126 swabs yielded to the growth of avian mycoplasma on mycoplasma agar.

\section{DISCUSSION}

From this study, the antibody titres of Mycoplasma gallisepticum and M. synoviae for the indigenous chickens sampled were high which implies that there was active antibody production due to challenge with Mycoplasma from both vertical and horizontal ways of transmission. The local chickens appeared normal without any obvious clinical signs. This result was similar to the findings of previous authors (Carpenter et al., 1981; Lierz et al., 2000; Lierz et al., 2002; Lierz et al., 2008; Peebles et al., 2004) who found high seroprevalence of Mycoplasma in birds of prey even though the adult birds remained clinically normal. This can be attributed to the type of husbandry system practiced by the villagers and including lack of vaccination of local chickens and non-existence of mycoplasma control program in Nigeria. It is established that antibodies to MG and MS may be produced locally before they become evident in the circulation of birds (Jordan, 1981). The inflammatory response to infection with mycoplasma is believed to depend on factors, such as virulence and tropism of the strain, the number of organisms and the route of infection, as well as the age, breed, concurrent infection and immune status of the host (Jordan, 1981). Furthermore, Mycoplasma species have been reported to propagate intracellularly (Vogl et al., 2008). This intracellular persistence is believed to be the cause of chronicity of avian mycoplasma. The apparent advantages of entering eukaryotic cells are protection from the host's immune system and easy access to nutrients. Mycoplasmas are also reported to invade chicken erythrocytes (Vogl et al., 2008). By so doing the Mycoplasma evade destruction by the immune system. A major advantage of entering erythrocytes is that it is a means to reach new sites of infection. This systemic spread via the blood stream explains how the Mycoplasma reaches distant niches after the first colonization of the respiratory system. It has also been established that the isolation of the organisms is the strongest evidence of an infection (Jordan 1981). In this study, the organisms were isolated when agar plates containing mycoplasma growth were observed under light microscope, colonies appeared smooth with entire margins. Colonies possessed a central dark area (nipple) and a translucent periphery identical to fried egg appearance.

\section{CONCLUSION}

Mycoplasmosis due to M. gallisepticum and $M$. synoviae infection is present among local chickenpopulation in Niger State. MG/MS Elisa can be used even in the field to screen birds for Avian Mycoplasmosis due to MG and MS infection.

\section{REFERENCES}

Abdu PA, Bishu G, Adesiyun AA, Adeboye DS (1983). Survey of Mycoplasma gallisepticum and Mycoplasma synoviae antibodies in chickens in Zaria, Nigeria. Journal of Animal Production and Research,1: 63-69.

Adegboye DS (1983). Chronic Respiratory Disease of poultry in Nigerian-Proposal for the institution of a national control program.Presented at the 20th Annual Conference Nigerian Veterinary Medical Association, Nov. 2-4, Benin City. Bendel State.

Barua SR, Prodhan AM, Chowdhury S (2006). Study on Mycoplasma gallisepticum in Chickens in selected areas of Bangladesh. Bangladesh Journal of Veterinary Medicine, 4 (2): 141-142.

Bencina D, Tadina T, Dorrer D (1988). Natural infection of ducks with Mycoplasma synoviae and Mycoplasma gallisepticum and mycoplasma egg transmission. Avian Pathology, 17: 441449 .

Carpenter TE, Mallinson ET, Miller KF, Gentry RF, Schwartz LD (1981). Vaccination with Fstrain Mycoplasma gallisepticum to reduce production losses in layer chickens.Avian Diseases, 25:404-409.

Hossain KMM, Ali, MY, Haque M I (2007). Seroprevalence of Mycoplasma gallisepticum 
infection in chicken in the greater Rajshahi district of Bangladesh. Bangladesh Journal of Veterinary Medicine,5 (1 and 2): 09-14

Jordan FTW (1981). Mycoplasmosis in poultry. Israel Journal of Medical Science, 17:540-547.

Jordan F, Pattison M, Alexander D, Faragher T, Textbook of Poultry Diseases. In Bradbury JM (2001). Fifth Edition, eds. W.B. Saunders, London, UK, 178-193.

Ley DH, Yoder HW (1997). Mycoplasma gallisepticum infection. In: Disease of poultry, edited by Calnek BW, Barnes H, Beard CW, Mcdougald LR and Saif YM, Ames, Iowa, USA. Iowa State University Press, pp 194 -207.

Lierz M, Schmidt R, Brunnberg L, Runge M (2000). Isolationof Mycoplasma meleagridis from free-ranging birds of prey inGermany. Journal of Veterinary Medicine, 47: 63-67.

Lierz M, Schmidt R and Runge M (2002). Mycoplasma species isolated from falcons in the Middle East. Veterinary Record, 151: 92-93.

Lierz M, Hagen N, Lueschow D, Hafez HM (2008). Use of polymerase chain reactions to detect Mycoplasma gallisepticum, Mycoplasma imitans, Mycoplasma iowae, Mycoplasma meleagridis and Mycoplasma synoviae in birds of prey. Avian Pathology, 375: 471- 476.
Olabode AO, Lamorde AG, Shidali NN, Chukwuedo AA (1992).Village chickens and Newcastle disease in Nigeria. Australian centre for international research proceedings, 39: 159 160.

Peebles ED, Parker TA, Branton SL, Willeford KO, Jones MS, Gerard PD, Pharr GT, Maslin WR (2004). Effects of an S6 Strain of Mycoplasma gallisepticum inoculation before beginning of lay on leukocytic characteristics of commercial layers. Avian Diseases, 48: pp 196201.

Pradhan MAM (2002). Studies on Avian Mycoplasmosis: Prevalence, Isolation, Characterization and Antigenic properties. $P h D$. Thesis Submitted to the Dept. of Microbiology and Hygiene, Faculty of Veterinary Science, Bangladesh Agricultural University, Mymensingh, Bangladesh.

Vogl G, Astrid P, Susan S, László S, Renate R, Michael PS (2008). Mycoplasma gallisepticum invades Chicken erythrocytes during infection. Infection and immunity, 76:( 1).71-77. 